\title{
CALVINISME DAN ILMU PENGETAHUAN: SUATU TINJAUAN FILOSOFIS TERHADAP PEMIKIRAN ABRAHAM KUYPER DAN IMPLIKASINYA PADA ETIKA ILMU PENGETAHUAN
}

\author{
Antonius Steven Un \\ Sekolah Tinggi Teologi Reformed Injili Internasional
}

\begin{abstract}
This article is focused on systematic explanation of Abraham Kuyper's thought on Calvinism and science. Some of significant contributions of Calvinism are the theological foundation of science and its liberation from church's invasion. This article uses a philosophical approach in its methodology and not a theological one. Therefore, I frequently make critical dialogues with the philosophy of science in reading and analyzing Kuyper's notion. Final ending of this research is an articulation of its implications to the ethics of science. On this point, I will consider the contribution of David Resnick.
\end{abstract}

KEYWORDS: Calvinism, science, Abraham Kuyper, ethics.

ABSTRAK: Artikel ini berfokus kepada uraian sistematis terhadap gagasan Abraham Kuyper dalam ceramahnya tentang Calvinisme dan ilmu pengetahuan. Sumbangan penting Calvinsime adalah pendasaran teologis bagi ilmu pengetahuan dan pembebasannya dari kungkungan gereja. Metodologi dari artikel ini adalah suatu penelitian filosofis, bukan penelitian teologis. Karena itu, penulis banyak berdialog secara kritis dengan filsafat ilmu dalam membaca dan menganalisis gagasan Kuyper. Ujung akhir dari penelitian ini adalah upaya artikulasi implikasi-implikasi bagi etika ilmu pengetahuan. Pada tataran ini, penulis mempertimbangkan sumbangan pemikiran David Resnick. 
KATA KUNCI: Calvinisme, ilmu pengetahuan, Abraham Kuyper, etika.

\section{Pengantar}

Abraham Kuyper (1837-1920) adalah satu di antara sedikit orang dalam sejarah yang menggenapkan impian Plato. Plato merindukan kepemimpinan filsuf-raja atas suatu negara. Dalam sejarah, sepanjang yang diketahui penulis, paling tidak ada tiga pemimpin negara yang berlatar belakang filsafat yakni Marcus Aurelius (121-180), Kaisar Romawi; Sarvepalli Radhakrishnan (1888-1975), presiden India dari tahun 1962-1967; dan tentu Kuyper sendiri yang menjadi Perdana Menteri Belanda pada tahun 1901-1905.

Selain sebagai Perdana Menteri, Kuyper juga memberikan banyak sumbangan politis dan kultural dalam sejarah Belanda. Sejarawan James D. Bratt menganggap Kuyper sebagai salah satu "significant figure" dalam sejarah negara Belanda․ Betapa tidak, Kuyper adalah tokoh kunci yang merintis harian De Standaard (1872); pendiri dari partai politik AntiRevolusioner (1878) dan pendiri Vrije Universiteit Amsterdam (1880)². Pada tahun 1888 ia berhasil merintis suatu koalisi politis dengan sayap politik Katolik yang dipimpin oleh Hermanus Schaepman. Koalisi politis ini kemudian berkembang dan membentuk suatu koalisi yang lebih besar antara kelompok Anti-Revolusioner yang dipimpin Kuyper, juga sayap Katolik dan kelompok Kristen historis.

Meskipun Kuyper lebih utama dikenal sebagai teolog dari aliran NeoCalvinisme namun sejak mula ia telah berkecimpung dalam pemikiran

\footnotetext{
1 James D. Bratt, ed. Abraham Kuyper: a Centennial Reader (Grand Rapids \& Carlisle: William B. Eerdmans \& Paternoster, 1998), 1.

2 The Editors of Encyclopaedia Britannica, "Abraham Kuyper: Dutch Theologian and Statesman", Encyclopaedia Britannica, http://www.britannica.com/biography/Abraham-Kuyper (diakses pada 29 Desember 2015).
} 
filosofis. Kuyper mempelajari filsafat, bersamaan dengan literatur dan teologi dalam studi sarjana di Universitas Leiden, Belanda. Pada tahun 1858, ia memeroleh propedeuse dalam bidang filsafat dengan hasil summa cum laude 3 . Tidak heran, dalam tulisan-tulisan teologisnya, Kuyper banyak berdialog secara kritis dengan pemikiran para filsuf, mulai dari Yunani kuno hingga era Modern dan Pencerahan. Hal ini kemudian memicu banyak pemikir masa kini menulis kajian perbandingan antara pemikiran Kuyper dengan sejumlah filsuf kontemporer ${ }^{4}$.

Pada tahun 1898, Kuyper diundang oleh Universitas Princeton di Amerika Serikat untuk mengajar dalam sebuah kuliah bergengsi Stone Lecture. Dalam kesempatan yang hebat itu, Kuyper menyampaikan enam kuliah yang diberi judul olehnya, Lectures on Calvinism ${ }^{5}$. Ia membuka seri kuliah ini dengan membahas Calvinisme sebagai sebuah weltanschauung, kemudian berturut-turut hubungan Calvinisme dengan: agama, politik, ilmu pengetahuan, seni dan masa depan. Di dalam ceramah yang keempat tentang Calvinisme dan ilmu pengetahuan, Kuyper membela satu tesis bahwa Calvinisme memberi sumbangan penting bagi penelitian ilmiah. Dalam kalimatnya sendiri, Kuyper mengatakan, "There is found hidden in Calvinism an impulse, an inclination, an incentive, to scientific investigation"6. Dalam konteks yang lebih dekat, Kuyper memaparkan sumbangsih Calvinisme Belanda bagi kemajuan ilmu pengetahuan. Katanya, "It is an undeniable fact, that the Calvinistic Netherlands had love for science

\footnotetext{
3 David Knibbe, "Abraham Kuyper", VU.nl, http://www.hdc.vu.nl/nl/Images/David_Knibbe_A_Kuyper_tcm215-350144.pdf (diakses pada 29 Desember 2015).

4 Sebagai contoh: Kent A. Van Til, "Abraham Kuyper and Michael Walzer: the Justice of the Spheres" dalam Calvin Theological Journal, Volume 40 (2005): 267-89. Contoh lain, Gordon Graham, "Kuyper, Neo-Calvinism and Contemporary Political Philosophy" dalam The Kuyper Center Review, Vol. 1: Politics, Religion and Sphere Sovereignty, ed. Gordon Graham (Grand Rapids: William B. Eerdmans, 2010).

5 Abraham Kuyper, Lectures on Calvinism (Grand Rapids: William B. Eerdmans, 1931).

6 Ibid., 110.
} 
and fostered it"7. Beberapa bukti di antaranya adalah bahwa teleskop, mikroskop dan termometer ditemukan di negeri Belanda dalam pengaruh Calvinisme ${ }^{8}$. Dengan tiga instrumen ini, maka penelitian empiris menjadi mungkin.

Artikel ini berfokus kepada uraian sistematis terhadap gagasan Kuyper dalam ceramahnya tentang Calvinisme dan ilmu pengetahuan. Metodologi dari artikel ini adalah suatu penelitian filosofis, bukan penelitian teologis. Karena itu, penulis banyak berdialog secara kritis dengan pemikiran filsafat ilmu dalam membaca dan menganalisis gagasan Kuyper. Ujung akhir dari penelitian ini adalah upaya artikulasi implikasi-implikasi bagi etika ilmu pengetahuan.

\section{Definisi Calvinisme}

Pertama-tama tentu penulis akan memaparkan apakah yang dimaksudkan oleh Kuyper dengan Calvinisme. Kuyper menyebut beberapa penggunaan terminologi "Calvinisme" yang relevan. Yang pertama adalah penggunaan konfesional. Dalam pengertian ini, Calvinisme dipahami sebagai sebuah sistem eksklusif yang memercayai dogma predestinasi ${ }^{9}$. Penyebutan ini bersifat menyindir. Dengan menyebut seseorang Calvinis, maka orang tersebut sedang dituding sebagai "a victim of dogmatic narrowness"10. Selain penggunaan konfesional, terdapat juga penggunaan denominasional ${ }^{11}$. Penggunaan ini terkait dengan pembedaan aliran-aliran atau denominasi-denominasi dalam kekristenan seperti denominasi Baptis,

\footnotetext{
$7 \quad$ Ibid., 112 . Penekanan oleh Kuyper sendiri.

8 Kuyper menguraikan hubungan para peneliti Belanda (antara lain Hans Lippershey, Zacharias Janssen, dan Cornelis Drebbel) yang menemukan alat-alat ini dengan Universitas Leiden yang berlatar belakang Calvinis. Lihat Kuyper, Lectures on Calvinism, 110-12.

$9 \quad$ Ibid., 13.

10 Ibid.

11 Ibid.
} 
Metodis dan lain sebagainya. Penggunaan yang pertama berfokus kepada isi ajaran, sedangkan penggunaan yang kedua lebih dipahami sebagai nama aliran institusional.

Kuyper memaksudkan istilah Calvinisme dalam pengertian ilmiah (scientific). Nama ilmiah dari Calvinisme mengandung tiga dimensi yakni sejarah, filosofis dan politis ${ }^{12}$. Secara historis, istilah Calvinisme berkaitan dengan gerakan teologi dalam arus Reformasi abad ke-16 yang dibedakan dari kelompok Lutheran, Anabaptis atau Socinian. Secara filosofis, Calvinisme dipahami sebagai "system of conceptions which, under the influence of the master-mind of Calvin, raised itself to dominance in the several spheres of life"13. Secara politis, Kuyper berpandangan bahwa Calvinisme mengindikasikan suatu gerakan yang menjamin pelaksanaan kebebasan konstitusional di beberapa negara seperti Belanda, Inggris dan kemudian Amerika Serikat.

Sebagai sebuah sistem teologi, Calvinisme tidak mungkin dilepaskan dari Allah dalam metafisikanya. Berangkat dari metafisika Allah, Kuyper melihat bahwa Calvinisme mengembangkan hubungan fundamental antara manusia dengan Allah, dengan sesama dan dengan dunia ${ }^{14}$. Mengikuti tradisi Calvinisme yang dimulai oleh reformator John Calvin (1509-1564), yang menekankan kedaulatan Allah, Calvinisme tidak mencari Allah di dalam ciptaan, tidak mengurung Allah dalam ciptaan dan tidak menjadikan manusia menjadi pengantara antara Allah dan dunia. Kuyper mengatakan bahwa Calvinisme "proclaims the exalted thought that, although standing in high majesty above the creature, God enters into immediate fellowship with the creature, as God the Holy Spirit"15. Kuyper mengatakan bahwa pada tataran

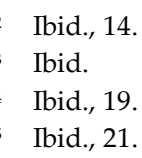


inilah terdapat jantung dari doktrin predestinasi yang sangat terkenal itu. Dari sini, kita dapat memahami bahwa Calvinisme, sebagaimana dinyatakan oleh Kuyper, menghendaki agar "the whole of a man's life is to be lived as in the Divine presence"16. Inilah keyakinan fundamental dalam Calvinisme.

Implikasi dari gagasan ini adalah timbul suatu model paradoks dalam relasi antara manusia. Pada satu sisi, individu-individu manusia bersifat sama rata di hadapan Allah sehingga dalam pandangan Kuyper, tidak mungkin dapat timbul klaim penguasaan dari satu manusia atas manusia lain ${ }^{17}$. Pada sisi lain, karena Allah menciptakan manusia menurut keunikan masing-masing maka Kuyper mengatakan bahwa "There is no uniformity among men, but endless multiformity"18. Kuyper melanjutkan bahwa sudah tentu Calvinisme akan menyalahkan semua sistem perbudakan, kastanisasi, pemerintahan tiranis, oligarkis dan seterusnya.

Kuyper kemudian menyimpulkan pandangan Calvinisme tentang ketiga relasi fundamental. Katanya, "For our relation to God: an immediate fellowship of man with the Eternal, independently of priest or church. For the relation of man to man: the recognition in each person of human worth, which is his by virtue of his creation after the Divine likeness, and therefore of the equality of all men before God and his magistrate. And for our relation to the world: the recognition that in the whole world the curse is restrained by grace, that the life of the world is to be honored in its independence, and that we must, in every domain, discover the treasures and develop the potencies hidden by God in nature and in human life"19.

\footnotetext{
Ibid., 25. Penekanan oleh Kuyper sendiri.

Ibid., 27.

Ibid., 26.

9 Ibid., 31. Penekanan oleh Kuyper sendiri.
} 


\section{Legitimasi Religius bagi Penelitian IImiah}

Kuyper memaksudkan ilmu pengetahuan sebagai suatu bidang yang bersifat umum, bukan hanya hard sciences atau sciences exactes dalam khazanah dunia ilmiah Perancis ${ }^{20}$. Dengan ilmu pengetahuan, Kuyper memaksudkan suatu sistem pengetahuan yang tidak hanya terdiri dari fakta-fakta empiris tetapi juga hukum-hukum universal yang mengatur fakta-fakta empiris tersebut dan gagasan-gagasan yang mengendalikan keseluruhan konstelasi fenomena ${ }^{21}$. Dengan ini, Kuyper memahami ilmu pengetahuan secara luas, bukan hanya terbatas pada penelitian empiris melainkan juga pada konstruksi rasional dari hukum-hukum abstrak yang mengendalikan fenomena-fenomena empiris tersebut. Hal ini sejalan dengan pemaparan The Liang Gie tentang lima ciri ilmu pengetahuan ${ }^{22}$. Pertama, ilmu pengetahuan bersifat empiris di mana bahan mentahnya diperoleh dari observasi, eksperimen dan sebagainya. Kedua, sifat sistematis. Data dan informasi yang dihimpun kemudian disusun dalam suatu tatanan, urutan dan hubungan yang teratur dan saling tergantung satu dengan yang lain. Ketiga, sifat obyektif, suatu impian untuk bebas dari prasangka peneliti dan kepentingan personalnya. Keempat, ilmu pengetahuan bersifat analitis artinya terdapat suatu klasifikasi, definisi, silogisme yang jelas dan teratur. Kelima, sifat verifikatif yakni dapat diuji dan dianalisis kebenarannya.

Titik berangkat Calvinisme tentu adalah Allah sebagai Pencipta keteraturan. Bahwa Allah yang berdaulat menjadikan suatu paket ciptaan yang menyeluruh dan teratur di bawah sejumlah hukum dan Allah-lah yang menopang ciptaan tersebut ${ }^{23}$. Dengan langkah ini, Kuyper meletakkan

\footnotetext{
$20 \quad$ Ibid., 112.

21 Ibid., 112-13.

22 Teks diambil dari Konrad Kebung, Filsafat Ilmu Pengetahuan (Jakarta: Prestasi Pustaka, 2011), 68-69.

23 Kuyper, Lectures on Calvinism, 114.
} 
fondasi religius bagi alam semesta yang teratur. Keteraturan ini merupakan impian dari banyak filsuf modern. Katanya, "The systems of the great modern philosophers are, almost to one, in favor of unity and stability" 24 . Dengan demikian, alam semesta bukanlah suatu perputaran yang tak jelas arah dan tak tentu melainkan berada di bawah kendali aturan-aturan yang mengatur agar teratur. Ontologi alam semesta demikian, bersifat penting. Bagi Kuyper, "the entire development of science in our age presupposes a cosmos which does not fall a prey to the freaks of chance, but exists and develops from one principle, according to a firm order, aiming at one fixed plan"25. Tanpa adanya keyakinan yang mendalam terhadap adanya suatu tatanan teratur di atas dasar hukum-hukum yang ditetapkan oleh Allah maka ilmu pengetahuan akan berjalan dalam dugaan-dugaan saja. Dengan keyakinan bahwa Allah menetapkan sejumlah aturan, maka ilmu pengetahuan dapat bergerak makin abstrak dari investigasi empiris atas fenomena hingga ke hukum-hukum dan hingga ke prinsip dan praanggapan yang melandasinya ${ }^{26}$.

Benarlah apa yang dikatakan Kuyper bahwa pemikir modern meyakini alam semesta yang teratur. Ilmuwan Isaac Newton (1643-1727) meyakini alam semesta seperti sebuah perangkat yang bekerja di bawah hukum sebab akibat (cause-effect law) ${ }^{27}$. Newton dapat secara cermat menjelaskan gerakan bumi yang diketahui dengan berangkat dari hukum gravitasi universal dan tiga hukum gerakan yang diyakininya termasuk hukum gerakan seragam serta dengan bantuan deduksi matematis ${ }^{28}$.

\footnotetext{
24 Ibid.

25 Ibid., 115.

26 Ibid.

27 Akhyar Yusuf Lubis, Filsafat Ilmu: Klasik Hingga Kontemporer (Jakarta: RajaGrafindo Persada, 2014), 123.

28 Alan W. Rice, “Kosmologi Science Modern” dalam Membangun Wawasan Dunia Kristen, Eds. W. Andrew Hoffecker \& Gary Scott Smith, 2 vols, Terj. Peter S. Wong (Surabaya: Momentum, 2008), 2:82.
} 
Newton menangkap keteraturan yang diciptakan Tuhan dalam alam semesta. Tidak heran, penyair pencerahan Alexander Pope dengan girang menyatakan "Nature and Nature's Laws lay hid in night: God said, Let Newton be! And all was Light"29. Newton yang memercayai Alkitab sebagai firman Allah dan membacanya setiap hari ${ }^{30}$ tentu mengikuti ilmuwan besar Johannes Kepler (1571-1630). Kepler adalah ilmuwan yang menemukan keteraturan perlintasan planet mengelilingi matahari. Ia kemudian menuangkannya dalam tiga hukum. Hukum yang pertama bahwa planetplanet mengitari matahari dalam lintasan berbentuk elips. Kepler meyakini bahwa alam semesta merupakan sebuah buku di mana rencana Ilahi dituliskan di dalamnya ${ }^{31}$. Kepler meyakini bahwa alam semesta bagaikan cermin yang merefleksikan gagasan-gagasan ilahi.

Selain itu, dalam pandangan Kuyper, Calvinismelah yang berjasa merehabilitasi ilmu pengetahuan kosmis. Kuyper membuat suatu perbandingan mengejutkan. Bahwa apa yang dipikirkan Aristoteles tentang ilmu pengetahuan jauh lebih banyak dibandingkan dengan semua gagasan ilmu pengetahuan dalam pemikiran bapak-bapak gereja, bahkan bila semuanya digabungkan ${ }^{32}$. Bahkan Kuyper beranggapan bahwa ilmu pengetahuan lebih berkembang dalam pemikiran Islam ketimbang dalam pemikiran gereja di Eropa pada masa kegelapan abad pertengahan. Dalam pandangan Kuyper, Calvinisme menolak posisi dualistis dalam melihat relasi antara dunia natural dan dunia supranatural, bumi dan surga.

\footnotetext{
29 Teks dalam Rice, “Kosmologi Science Modern”, 2:83.

30 Ann Lamont, Para Ilmuwan Mempercayai Ilahi, Terj. L.D Tedjasudhana (Jakarta: YK Bina Kasih, 1999), 57. Kutipan lengkap perkataan Newton: "Saya sangat percaya bahwa Alkitab adalah Firman Allah yang ditulis oleh orang-orang yang memperoleh wahyu. Saya mempelajari Alkitab setiap hari". Kalimat ini dikutip Lamont dari J. H Tiner, Isaac Newton: Inventor, Scientist and Teacher (Milford, MI: Mott Media, 1975). Lamont sendiri adalah seorang ahli matematika. 31 Robert S. Westman, "Johannes Kepler: German Astronomer", Encyclopaedia Britannica, http://www.britannica.com/biography/Johannes-Kepler (diakses pada 30 Desember 2015). 32 Kuyper, Lectures on Calvinism, 117.
} 
Calvinisme tidak menghendaki orang Kristen hanya berorientasi pada keselamatan yang kekal di dalam surga dan tidak memberi perhatian pada dunia yang diciptakan oleh Allah. Kuyper menegur, "It has, on account of its too intense contemplation of celestial things, neglected to give due attention to the world of God's creation. It has, on account of its exclusive love of things eternal, been backward in the fulfillment of its temporal duties" 33 . Kuyper menuding gereja terlalu eksklusif memahami Kristus dalam signifikansi soteriologisnya sehingga signifikansi kosmologisnya menjadi hilang ${ }^{34}$. Padahal, Alkitab jelas menegaskan bahwa Kristus bukan hanya Penebus melainkan juga Pencipta alam semesta, Pencipta langit dan bumi. Lagipula, pengakuan-pengakuan iman Calvinistik mengajarkan bahwa manusia mengenal Allah melalui dua sarana yakni alam dan Alkitab ${ }^{35}$. Sampai di sini, Kuyper melihat relasi erat antara Calvinisme dan Humanisme. Katanya, "In as far Humanism endeavored to substitute life in this world for the eternal, every Calvinist opposed the Humanist. But in as much as teh Humanist contented himself with a plea for a proper acknowledgment of secular life, the Calvinist was his ally" ${ }^{\prime 36}$.

Apa yang dimaksudkan Kuyper tentu soal peran Calvinisme dalam kekristenan dan bukan dalam sejarah umat manusia. Sebab, dalam sejarah umat manusia, peran pemikir Renaisans amat penting bagi perkembangan ilmu pengetahuan. Jerome R. Ravertz menyatakan bahwa salah satu sumber yang penting bagi kebangkitan kembali ilmu pengetahuan pada masa Renaisans adalah penemuan manusia dan alam melalui suatu produk artistik abad 15 di Italia ${ }^{37}$. Ilhamnya tentu berasal dari zaman klasik kuno

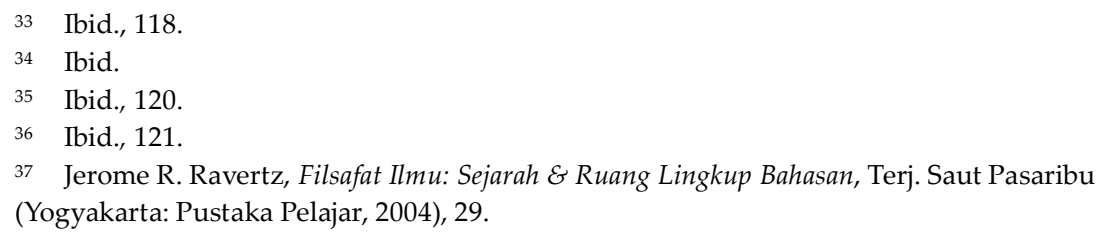


dan para pemikir humanis Renaisans terinspirasi oleh teks kuno berbahasa Latin dan Yunani. Karya Leonardo da Vinci dalam berbagai bidang baik artistik maupun sains merupakan contoh utama untuk hal ini. Kelahiran kembali pemikiran Yunani dan Romawi kuno tampak dalam nama gerakan dan jaman itu yakni "renaisans". Istilah "renaisans" berasal dari bahasa Prancis renaissance yang secara harafiah berarti "kelahiran kembali" 38 . Istilah yang mendahuluinya adalah terminologi Italia rinascita. F. Budi Hardiman menegaskan bahwa apa yang dilakukan para pemikir Renaisans bukanlah sekadar produksi ulang namun lebih tepatnya adalah penafsiran baru terhadap pemikiran $\mathrm{kuno}^{39}$. Penemuan kembali manusia sebagaimana disinggung oleh Ravertz di atas melalui jalan mencari inspirasi kepada pemikiran klasik akhirnya memunculkan gerakan humanisme. Hardiman menyebut tiga nilai yang dihidupkan kembali oleh gerakan humanisme pada masa Renaisans yakni penghargaan atas dunia-sini, penghargaan atas martabat manusia dan pengakuan atas kemampuan rasio ${ }^{40}$. Nilai yang terakhir ini kemudian dilanjutkan oleh langkah-langkah kepercayaan akan kemampuan manusia, hasrat intelektual dan penghargaan akan disiplin intelektual $^{41}$. Dalam dunia filsafat ilmu, muncul pemikir Renaisans seperti Nicolas Copernicus (1473-1543) dan Galileo Galilei (1564-1642).

Meski kebangkitan ilmu pengetahuan dimulai oleh pemikir Renaisans namun peran Reformasi - di mana Calvinisme menjadi bagian di dalamnya tidak bisa dipandang sebelah mata. Tidak heran, Hardiman berani menyimpulkan, "Renaisans dan Reformasi dapat dipandang sebagai gerakan-gerakan yang sejalan yang sama-sama melahirkan masyarakat

\footnotetext{
38 F. Budi Hardiman, Filsafat Modern: Dari Machiavelli sampai Nietzsche (Jakarta: Gramedia Pustaka Utama, 2004), 8.

39 Hardiman, Filsafat Modern, 9.

40 Ibid.

41 Ibid., 10.
} 
modern ini" ${ }^{42}$. Kritikan para reformator: Martin Luther (1483-1546) dan juga John Calvin (1509-1564) terhadap dominasi korup gereja dapat dianggap sebagai suatu pemberontakan intelektual. Meski demikian, jalan yang ditempuh gerakan Renaisans dan Reformasi sangat berbeda. Perbedaan utamanya, sebagaimana diungkapkan oleh Hardiman adalah terletak pada pemahaman subyektivitas. Bila Renaisans menekankan kemampuan rasional individual maka Reformasi melihat subyektivitas sebagai iman personal ${ }^{43}$. Penulis berpandangan bahwa gerakan Reformasi meneruskan keyakinan teolog dan filsuf abad pertengahan, Anselmus (1033-1109) yaitu "fides quaerens intellectum". Simon Petrus L. Tjahjadi menerjemahkan teks ini sebagai "iman berikhtiar menemukan pemahaman atau pengertian"44. Tjahjadi menjelaskan keyakinan Anselmus bahwa iman selalu merupakan titik tolak pemikirannya dan iman sulit dibantah oleh argumentasi rasional. Malah sebaliknya, akal budi yang sejati seharusnya dapat menangkap dan memikirkan kebenaran-kebenaran iman secara rasional ${ }^{45}$. Dalam konteks filsafat ilmu, Reformasi bersumbangsih membangkitkan keberanian masyarakat untuk memikirkan hal-hal baru di luar yang telah ditetapkan oleh gereja melalui keyakinan akan ajaran Alkitab sebagai firman Allah.

\section{Anugerah Umum dan IImu Pengetahuan}

Tidak bisa dipungkiri, dalam konteks rehabilitasi dunia ilmu pengetahuan, doktrin anugerah umum berperan sangat penting. Anugerah keselamatan dalam terang teologi Calvinisme adalah anugerah yang dicurahkan bagi orang berdosa sehingga ia berdamai dengan Allah dan

\footnotetext{
42 Ibid., 12.

43 Ibid., 13.

44 Simon Petrus L. Tjahjadi, Petualangan Intelektual: Konfrontasi dengan Para Filsuf dari Zaman Yunani hingga Zaman Modern (Yogyakarta: Kanisius, 2004), 123.

45 Ibid.
} 
memeroleh pengampunan dosa, hidup baru dan hidup kekal. Sementara itu, anugerah umum adalah anugerah yang diberi kepada semua manusia tanpa memertimbangkan status religius atau moral-etisnya. Kuyper menyebut filsuf Plato dan Cicero sebagai contoh betapa Tuhan mencurahkan anugerah umum di dalam dan melalui mereka bagi umat manusia46. Kuyper berpandangan bahwa anugerah umum diberikan oleh Tuhan untuk mengekang dosa sehingga tidak menyebabkan kemerosotan yang lebih jauh dan mencegah kemusnahan total dari pekerjaan tangan Allah sendiri ${ }^{47}$. Kuyper menyimpulkan bahwa melalui terang anugerah umum, telah muncul segala kekayaan filosofis, seni, keadilan, studi klasik (filologi) dan sebagainya ${ }^{48}$.

Selain dalam Lectures on Calvinism, Kuyper juga membahas doktrin anugerah umum dalam artikelnya Common Grace in Science yang diterbitkan pada tahun $1904^{49}$. Dalam artikel ini, Kuyper menandaskan landasan bagi ilmu pengetahuan manusia yakni gagasan Allah dalam kekekalan, ekspresi dalam alam semesta dan kemampuan manusia sebagai citra Tuhan untuk menangkap gagasan tersebut secara sistematis ${ }^{50}$. Secara logis, Allah berpikir dan kemudian menciptakan manusia sebagai makhluk yang berpikir. Sementara itu, di balik ciptaan Allah yang indah dan ajaib, terdapat gagasan dan rancangan Allah. Tugas manusia adalah menemukan gagasan dan rancangan Allah tersebut. Meskipun demikian, Kuyper menyangkal bahwa seluruh gagasan Allah dapat ditangkap oleh satu orang ${ }^{51}$. Pekerjaan ini terlalu luas dan terlalu berat sehingga harus menjadi tugas dari banyak

\footnotetext{
46 Kuyper, Lectures on Calvinism, 121.

47 Ibid., 123.

48 Ibid., 125.

49 Abraham Kuyper, "Common Grace in Science" dalam Abraham Kuyper: a Centennial Reader, ed. James D. Bratt (Grand Rapids \& Carlisle: William B. Eerdmans \& Paternoster, 1998), 441-60.

50 Kuyper, "Common Grace in Science", 445.

51 Ibid.
} 
orang untuk menemukan gagasan Allah dalam alam semesta yang diciptakan-Nya.

Pandangan Kuyper tentang gagasan Ilahi - alam semesta - dan pikiran manusia bukan merupakan gagasan yang asing bagi banyak ilmuwan. Salah satu contohnya adalah ilmuwan Johannes Kepler. Robert Westman mengatakan bahwa Kepler mempunyai pandangan yang serupa52. Kepler meyakini bahwa gagasan Ilahi tertera dalam alam semesta, dan Tuhan menciptakan akal budi manusia untuk menangkap struktur alam semesta yang diciptakan oleh Tuhan. Westman memberi dua contoh. Pertama, Allah Tritunggal dalam Alkitab dan disimbolkan ruang geometris di mana dunia kelihatan yang dicipta oleh Tuhan ini merefleksikan misteri Ilahi. Allah Bapa sebagai pusat, Allah Anak, Yesus Kristus sebagai keliling (circumference) dan Allah Roh Kudus sebagai ruang intervensi (intervening space). Contoh kedua adalah soal Yohanes 1:14. Ayat ini merupakan ayat kegemaran Kepler: "Firman itu telah menjadi manusia, dan diam di antara kita, dan kita telah melihat kemuliaan-Nya yaitu kemuliaan yang diberikan kepada-Nya sebagai Anak Tunggal Bapa, penuh kasih karunia dan kebenaran" ${ }^{23}$. Westman menulis, "For [Kepler], this signified that the divine archetypes were literally made visible as geometric forms (straight and curved) that configured the spatial arrangement of tangible, corporeal entities".

Sebagai pemikir yang menerima doktrin pewahyuan, sebagaimana telah disinggung sebelumnya, yakni Allah menyatakan diri melalui alam dan Alkitab, maka Kuyper tidak sedang membuktikan adanya Allah melalui jalan keterarahan alam. Jalan pemikiran ini diringkas oleh Franz MagnisSuseno sebagai berikut, “(1) Dalam alam terdapat proses-proses yang terarah ke suatu tujuan. (2) Keterarahan itu tidak dapat dijelaskan sebagai kejadian kebetulan. (3) Apabila proses-proses itu bukan kebetulan, proses-proses itu

\footnotetext{
52 Westman, “Johannes Kepler".

53 Terjemahan Baru dari Lembaga Alkitab Indonesia.
} 
hasil pengarahan. (4) Maka proses-proses terarah dalam alam semesta menunjuk pada realitas yang mengarahkan. (5) Realitas itu adalah apa yang kita sebut Tuhan"54. Lebih lanjut Magnis-Suseno menegaskan bahwa dasar argumentasi dari jalan keterarahan alam ini adalah bahwa terdapat realitas empiris dalam alam semesta terdapat banyak proses terarah yang kelihatannya teratur untuk menghasilkan sebuah tujuan di mana tanpa tujuan tersebut, proses-proses tersebut tidak dapat dipahami ${ }^{55}$. MagnisSuseno pun mengakui bahwa jalan ketararahan Tuhan tidak dimaksudkan untuk mencari "bukti tak terbantah" tentang adanya Tuhan tetapi untuk memberi pertanggungjawaban rasional atas iman akan adanya Tuhan ${ }^{56}$. Dalam konteks ini, Kuyper juga tidak sedang membuktikan adanya Tuhan melainkan menyatakan bahwa gagasan ilahi terekspresikan dalam alam semesta yang diciptakan-Nya.

\section{Implikasi bagi Etika IImu Pengetahuan}

Dalam seksi ini, penulis akan berupaya membuat implikasi pemikiran Kuyper bagi etika ilmu pengetahuan dengan jalan mengadakan dialog dengan pemikiran David B. Resnik, seorang bioetika. Pertama-tama secara ringkas penulis perlu memaparkan inti dan kepentingan etika. J. Sudarminta membedakan antara istilah "etika" dan "moral" 57. Yang pertama digunakan dalam ranah ilmiah sedangkan yang kedua dipakai dalam konteks legal. Bila yang kedua merujuk pada aturan konkret justifikasi baik-buruknya tindakan manusia maka yang pertama berkaitan dengan ilmu, prinsip, asumsi dasar dalam kajian ilmiah baik-buruknya tindakan manusia. Selain

\footnotetext{
54 Franz Magnis-Suseno, Menalar Tuhan (Yogyakarta: Kanisius, 2006), 136. Magnis-Suseno memberi penekanan pada teksnya.

55 Ibid.

56 Ibid., 146.

57 J. Sudarminta, Etika Umum: Kajian tentang Beberapa Masalah Pokok dan Teori Etika Normatif (Yogyakarta: Kanisius, 2013), 3.
} 
itu, Sudarminta juga memaparkan obyek material dan obyek formal dari ilmu etika ${ }^{58}$. Yang pertama adalah tindakan atau perilaku manusia sebagai manusia, sedangkan yang kedua adalah segi baik-buruknya atau benarsalahnya. Dalam konteks membicarakan obyek material, tentu yang dimaksud adalah actus humanus, dan bukanlah actus hominis ${ }^{59}$. Yang dikaji dalam ilmu etika bukanlah tindakan yang dilakukan manusia tetapi yang unik pada manusia saja yaitu yang dilakukan secara sadar dan bebas. Dalam konteks pembicaraan artikel ini, etika ilmu pengetahuan berkaitan dengan penerapan etika dalam bidang ilmu pengetahuan. Bagaimana prinsipprinsip etis digunakan untuk menganalisis tindakan manusia dalam kaitan dengan ilmu pengetahuan dan hal-hal terkait.

Berdasarkan kajian atas fakta-fakta penyimpangan etika penelitian ilmiah, Resnik berpandangan bahwa secara praktis, etika ilmu pengetahuan sangat diperlukan ${ }^{60}$. Bila etika tidak diperhatikan dalam penelitian ilmiah maka akan timbul kerugian pada pihak lain. Misalnya, pihak universitas merasa dirugikan karena fasilitas laboratorium digunakan secara pribadi oleh peneliti untuk melakukan penelitian rahasia bagi kepentingan industri dan keuntungan personal. Sementara itu, pihak peneliti juga dapat merasa dirugikan bila institusi tempat ia meneliti secara diam-diam menggunakan atau menjual hasil risetnya. Tentu yang paling dirugikan adalah kemanusiaan bila terdapat penelitian rahasia dengan menggunakan manusia atau organ tubuh manusia untuk suatu kepentingan tertentu. Berdasarkan fakta-fakta penyimpangan etis yang terjadi dalam dunia ilmu pengetahuan, Resnik mencoba mengartikulasikan sejumlah standar etika dalam penelitian ilmiah ${ }^{61}$. Sejumlah standar tersebut antara lain: kejujuran

\footnotetext{
$58 \quad$ Ibid., 4.

59 Ibid.

60 David B. Resnik, The Ethics of Science: an Introduction (London \& New York: Routledge, 1998), 1-5.

$61 \quad$ Ibid., 48-65.
} 
(honesty), kehati-hatian (carefulness), keterbukaan (openness), kebebasan (freedom), penghargaan (credit), pembelajaran (education), tanggung jawab sosial (social responsibility), keabsahan (legality), pemanfaatan kesempatan (opportunity), saling menghargai (mutual respect), efisiensi, dan penghargaan terhadap subyek, khususnya manusia.

Memerhatikan pemaparan Kuyper, kebutuhan akan etika ilmu pengetahuan tidak terbatas hanya pada dimensi praktis tetapi dimensi ontologis dari alam semesta yang dicipta oleh Tuhan dan diobservasi oleh peneliti. Secara sederhana, gagasan kebenaran ilahi yang terekspresikan dalam alam semesta yang diciptakan oleh Sang Khalik itu kemudian ditangkap oleh manusia melalui proses yang benar. Pada tataran ini, dapat dipahami bahwa etika penelitian membincangkan soal proses penggalian kebenaran ilahi secara benar. Prosesnya untuk menggali kebenaran haruslah benar. Hal ini sejalan dengan natur dari penelitian ilmu pengetahuan yakni upaya mencari kebenaran. Selain itu, etika juga dibutuhkan oleh manusia, tidak terbatas hanya pada penelitian ilmiah, untuk menjalankan hidup bermoral.

Karena itu, ada kebutuhan yang sangat besar bagi peneliti untuk memperjuangkan kejujuran. Resnik menyebut prinsip kejujuran sebagai aturan yang paling penting karena tanpanya tidak mungkin seorang peneliti dapat mencapai tujuan dari ilmu pengetahuan. Bukankah ilmu pengetahuan bertujuan untuk mengenali apa yang sesungguhnya terjadi atau apa yang sesungguhnya ada di dalam alam semesta ini? Resnik berkata, "Neither the search for knowledge nor the solution for practical problems can go forward when dishonesty reigns"62. Dalam kajiannya yang cermat, Resnik membedakan antara ketidakjujuran dan kelalaian (error). Apa yang membedakan antara ketidakjujuran dan kelalaian bukanlah hasil

62 Ibid., 48 . 
penelitiannya tetapi motivasinya. Keduanya dapat bermuara pada hasil penelitian yang sama tetapi motivasinya sangat berbeda. Resnik menjelaskan bahwa ketidakjujuran adalah tindakan yang melibatkan niat untuk menipu audiens yang mengharapkan adanya kebenaran ${ }^{63}$. Resnik menyebut beberapa tindakan yang tidak jujur antara lain: membuat data fiktif, tidak melaporkan hasil penelitian yang bertentangan dengan hipotesis, membuat hasil penelitian tampak lebih baik dari aslinya dan sebagainya ${ }^{64}$.

Bila melihat alam semesta sebagai ciptaan Tuhan yang di dalamnya nyata gagasan Ilahi dan manusia sebagai citra Tuhan maka seyogianya peneliti memerlakukan subyek penelitian secara hormat. Dalam pembahasan tentang penghormatan kepada subyek, Resnik mengatakan bahwa gagasan ini sepenuhnya didasarkan atas basis moral65. Dengan demikian, gagasan Resnik sejalan dengan gagasan Kuyper yakni bahwa etika ini didasarkan atas ontologi alam semesta. Meski demikian, Resnik lebih menitikberatkan pada argumentasi sosial dan yuridis. Secara sosial, banyak komunitas masyarakat yang melindungi entitas-entitas tertentu dari alam semesta. Itu sebabnya, bila peneliti tidak memperlakukan binatang atau tumbuhan, apalagi manusia dengan baik dalam penelitiannya, dapat memicu kemarahan publik. Lagi pula, secara yuridis, banyak entitas alam semesta yang dilindungi oleh hukum negara pada komunitas politik tertentu. Dengan demikian, kesalahan peneliti dapat menimbulkan dampak pidana.

Selain itu, alam semesta yang dicipta oleh Tuhan terbuka bagi manusia sebagai gambar Allah untuk meneliti apa saja di dalam alam semesta. Sebagaimana ditegaskan oleh Kuyper, tidak mungkin satu orang

\footnotetext{
63 Ibid.

64 Ibid., 49.

65 Ibid., 61.
} 
dapat menangkap seluruh kekayaan gagasan Allah dalam alam semesta. Karena itu, semakin banyak peneliti mencari semakin banyak gagasan semakin baik. Di sini, implikasi kebebasan dalam penelitian ilmiah sangat nyata. Dalam sejarah, sebagaimana diuraikan oleh Kuyper, salah satu sumbangsih penting Calvinisme adalah membebaskan peneliti untuk meneliti dan merumuskan hipotesis yang bahkan berbeda dengan yang digariskan oleh gereja atau yang diyakini oleh mayoritas ilmuwan pada masa tersebut. Kebebasan bereksperimen secara ilmiah sangat penting sebagaimana ditegaskan oleh Kuyper, "Liberty is for genuine science what the air we breathe is for us" 66 .

Resnik menegaskan bahwa kebebasan merupakan salah satu standar etika penelitian ${ }^{67}$. Setiap peneliti seharusnya bebas untuk meneliti pertanyaan apapun dan merumuskan hipotesis apa saja. Bahkan tidak tertutup kemungkinan, seorang peneliti menemukan hal baru dan mengkritik gagasan yang lama. Dalam pandangan Resnik, prinsip kebebasan membuka jalan bagi pencapaian tujuan ilmu pengetahuan dalam beberapa aspek ${ }^{68}$. Pertama, kebebasan berperan penting membuka peluang bagi peneliti untuk berekspansi secara ilmiah, menjelajah masuk ke ranahranah penelitian baru dan memunculkan pertanyaan-pertanyaan riset menggelitik yang luput dari sejarah ilmu pengetahuan. Kedua, kebebasan intelektual berperan dalam menyemai dan menyuburkan kreativitas ilmiah. Sudah jelas bahwa kreativitas intelektual akan terhenti di bawah tekanan. Kuyper mengatakan bahwa selama berabad-abad, kelompok penekan kreativitas itu adalah gereja dan negara ${ }^{69}$. Ketiga, kebebasan berperan untuk memberi ruang validasi bagi ilmu pengetahuan dengan mengijinkan peneliti

\footnotetext{
66 Kuyper, Lectures on Calvinism, 126.

67 Resnik, The Ethics of Science, 54.

68 Ibid.

69 Kuyper, Lectures on Calvinism, 127.
} 
mengkritik asumsi-asumsi dan gagasan-gagasan lama. Dengan adanya keterbukaan ini, maka ilmu pengetahuan tidak dapat menjadi stagnan dan tidak berpeluang terdegradasi menjadi ideologi. Keempat, Resnik mengatakan bahwa moralitas menyediakan argumentasi rasional bagi kebebasan dalam penelitian, yakni kebebasan untuk berpikir, menyatakan pendapat, berekspresi dan seterusnya.

\section{Kesimpulan}

Abraham Kuyper telah membuktikan bahwa agama secara umum dan Calvinisme secara khusus memberi sumbangan penting bagi perkembangan ilmu pengetahuan. Dengan ini, Kuyper tidak menempatkan ilmu dan agama pada dua kutub yang beroposisi secara diametris melainkan berelasi secara komplementer. Dengan ini pula Kuyper telah meletakkan fondasi religius bagi riset ilmu pengetahuan. Justru dengan adanya fondasi religius, agama tidak membelenggu riset ilmiah, malah membebaskannya. Meski demikian, dengan jalan ini maka kebutuhan akan etika ilmu pengetahuan menjadi lebih mendesak. Kebutuhan mendesak akan etika dalam penelitian ilmiah tidak lagi semata-mata soal-soal praktis dan untung-rugi tetapi terutama soal-soal metafisis dan ontologis. 